\title{
The Economic Value of the Pollination Service, a Review Across Scales
}

\author{
Lars Hein*
}

Environmental Systems Analysis Group, Wageningen University, P.O. Box 47, 6700 AA Wageningen, The Netherlands

\begin{abstract}
Pollination is an ecosystem service that is essential to support the production of a wide range of crops. The service is increasingly under threat, as a consequence of among others habitat loss of pollinators and increasing use of pesticides. In order to support maintaining the pollination service in agriculture, there is a need to better understand the economic value generated by the pollination service. This paper discusses the appropriate valuation methods for pollination at different scales, and presents an analysis of the value of the pollination service based on a literature review. At the local scale, the value of the service is highly variable depending on the crop and the market conditions. At the national scale, value estimates of the pollination service range from $1 \%$ to $16 \%$ of the market value of agricultural production. At the global scale, there is currently no reliable estimate of the value of this service. When the economic value of the pollination service is analysed, it is critical to adjust the valuation approach to the scale of the analysis.
\end{abstract}

Keywords: Pollination, ecosystem services, economic valuation.

\section{INTRODUCTION}

Pollination involves the transfer of genetic information between plants through pollen and is required for the sexual reproduction of plants. Pollination is required for the production of a wide range of crops including fruits (e.g. apples, mango), nuts and fibres, and it significantly increases yields of other crops such as coffee and oranges (e.g. Levin 1984; Gordon and Davis, 2003; Klein et al., 2007). Hence, pollination is a critical ecosystem service for food production and human livelihoods.

In the last decades, the provision of the pollination service by wild and managed pollinators has shown a gradual but steady decline. Causes for this decline include the general intensification of agriculture, the use of monocultures, parasites and diseases, pesticide use, urbanisation, and reductions in the availability of natural ecosystems nearby fields as a resting, foraging or nesting area for wild pollinators (Allen-Wardell et al. 1998; Kevan and Phillips, 2001; Biesmeijer et al., 2006). Although the loss of pollination services has, to date, been confined to local cases (e.g. Needham et al. 1988), there is a need to increase our understanding of pollination as a critical element in the world's food supply, and to raise the attention given to maintaining pollination services in agricultural management (Balmford et al., 2002; Klein et al., 2007).

One of the approaches available to raise the interest of farmers and policy makers in the conservation and sustainable use of pollination services is through the economic valuation of pollination. Because pollination services, in particular those provided by wild insects, are not traded in a market, their value may be insufficiently considered in decision making processes. However, estimates for the

*Address for correspondence to this author at the Environmental Systems Analysis Group, Wageningen University, P.O. Box 47, 6700 AA Wageningen, The Netherlands; Tel: + 31-317-482993; Fax: +31-317484839; E-mail: lars.hein@wur.nl

Handling Editor: Carsten Friederich Dormann economic value of the pollination service vary widely (e.g. Richards 1993; Costanza et al. 1997). Consequently, there is a need to review potential valuation methods and analyse the current understanding of the value of the pollination service. The way in which the pollination service generates economic value is scale dependent. At the local scale, the service supports farmer income, whereas the national scale the service is important for ensuring food supply. At these scales, the consumers and producers surpluses of the service vary, and different valuation methods need to be considered (e.g. Hanley and Spash 1993; Diaz et al., 2007).

The aim of this study is to analyse the economic value of the pollination service at different scales. The study has been conducted on the basis of (i) an analysis of the factors driving the economic value of pollination; and (ii) a literature review of valuation studies targeting the pollination service. The study focuses on insect pollination, because insects are the most important species group that act as pollinators (Allen-Wardell et al. 1998). The study only considers the impacts of pollination on agricultural production, since there is very little information on the economic benefits from pollination in non-agricultural ecosystems (Costanza et al. 1997). Specific attention is paid to the spatial scale at which the value of the service is assessed, and the consequences the selected scale has for the appropriate valuation methodology to be used. Section 2 of the paper examines the theoretical basis for analysing and valuing the pollination service at different scales, and Section 3 presents the results of a literature review on the value of pollination. Section 4 presents a discussion and the main conclusions.

\section{VALUING THE POLLINATION SERVICE}

\subsection{Analysing Ecosystem Services Supply Across Scales}

According to its original definition, ecosystems can be defined at a wide range of spatial scales (Tansley 1935). These range from the level of a small patch of less than a 
square meter up to the boreal forest ecosystem spanning several thousands of kilometres. In ecology, it has become common practice to distinguish a range of spatially and temporally defined ecological scales (Holling 1992; Levin 1992). They vary from the level of the plot, via ecosystems and biomes, to the global system.

Ecosystem services are the goods or services provided by the ecosystem to society (Costanza et al. 1997; Millennium Ecosystem Assessment (MA) 2003). Ecosystem services are generated at all ecological scales and they depend on the functioning of ecological processes over a range of spatial and temporal scales (MA 2003). For instance, the production of irrigated crops depends on the activity of micro-organisms at the scale of the plot, the supply of irrigation water that depends on processes taking place at the level of the landscape, and temperature and rainfall regulated by processes operating at the level of the biome or the globe.

Ecosystem services can be supplied to society at a range of institutional scales, ranging from households to the national state to the global community (O'Riordan et al. 1998; Berkes and Folke 1998; Peterson 2000). For instance, households may directly depend upon ecosystem services for their income (e.g. fishermen, ecotourism operators). Government agencies at different levels are involved in managing ecosystems, and in regulating the access to ecosystem services. They may also receive income from specific ecosystem services (e.g. park entrance fees). Ecological and institutional boundaries seldom coincide, and stakeholders in ecosystem services often cut across a range of institutional zones and scales (Cash and Moser 1998).

The analysis of ecosystem services across scales requires specification of the ecological scale at which the ecosystem service is generated, and the institutional scales of the stakeholders benefiting form this service (e.g. Limburg et al. 2002; Hein et al. 2006; Boyd and Banzhaf 2007). Pollination itself occurs at the level of the plant community, such as within an agricultural field. However, sustaining the pollination service depends on the functioning and characteristics of the ecosystem. The ecosystem harbours population of pollinators, for example it provides nesting opportunities to bees, and renders the pollination service to nearby agricultural fields. The stakeholders benefiting from this service include farmers but also, at a higher institutional scale, local and national consumers of the pollinated crops.

\subsection{The Value of Ecosystem Services Across Scales}

According to neo-classical welfare economics, the welfare generated by an ecosystem service is determined by the aggregated utility gained by all individuals as a result of the provision of the ecosystem service. The welfare resulting from the supply of an ecosystem service thus depends on the generated consumers and the producers surpluses (e.g. Freeman 1993). The consumer surplus has been defined as 'The excess of price which a consumer would be willing to pay rather than go without the thing, over that what he actually pays' (Marshall 1920; Willig 1976). The consumers' surplus generated by an ecosystem service equals the aggregated utility gained by all consumers of the service minus the aggregated costs or efforts involved in obtaining the ecosystem service (Hueting 1980).

The producer surplus indicates the amount of welfare a producer gains at a certain production level and for a certain market price (e.g. Van Kooten 1993). In the short term, the producer's surplus can be approximated on the basis of the difference between the gross revenues for the producer and his production costs (e.g. Varian 1993. In general, in the valuation of private ecosystem services, the producers

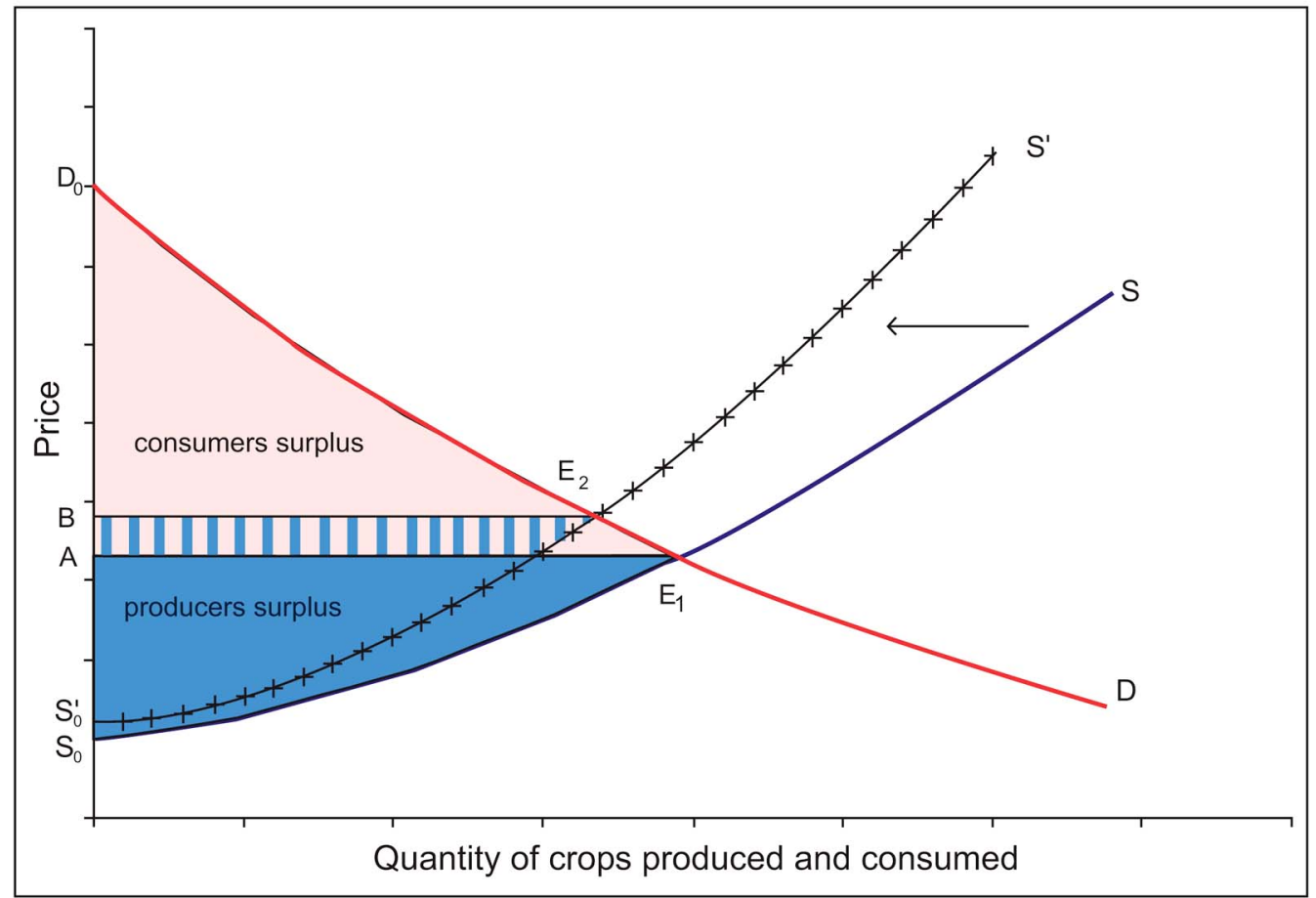

Fig. (1). Changes in the consumers and producers surplus in case pollination losses affect agricultural production. Pollination loss shifts the supply curve of agricultural producers from $S$ to $S$ '. The producers surplus changes from $S_{0} A_{1} E_{1}$ to $S_{0}{ }^{\prime} B E_{2}$. The consumers surplus changes from $\mathrm{D}_{0} \mathrm{AE}_{1}$ to $\mathrm{D}_{0} \mathrm{BE}_{2}$ (see text for further explanation). 
surplus needs to be considered if there are costs related to harvesting or processing the ecosystem good or service, or if the ecosystem service is used as input in a production process (Hueting et al. 1998).

The concepts of consumers and producers surplus, and how they depend on the demand curve (D) and supply curve (S), are depicted in Fig. (1). Fig. (1) shows that a decline in the pollination service may reduce agricultural production, and shift the supply curve to the left. In other words, farmers will obtain a lower harvest at relatively higher production costs. Consequently, a new market equilibrium (E2) is reached, at a higher food price and with a lower quantity of food traded in the market. The consumer surplus declines from $\mathrm{D}_{0} \mathrm{AE} 1$ to $\mathrm{D}_{0} \mathrm{BE} 2$. Changes in the producers surplus are moderated because there may also be producers that are not affected by a decline in the pollination service and that may benefit by obtaining a higher price for their crops. Below, it is analysed how changes in consumers and producers surpluses depend on scale.

In general, the total supply of an ecosystem service such as pollination is dependent on the (remaining) area and integrity of the ecosystem involved (e.g. Balmford et al. 2002). The subsequent impacts on consumers and producers surplus depend on the scale of the impact, in other words, the magnitude of the ecological change (Sanchirico et al. 2005). If pollinators are affected at the level of the field, the impact on agricultural production is likely to be small compared to the overall supply of that ecosystem service.

With regards to the consumers surplus, in case the farmer is producing for the international market, a local loss of the pollination service will generally not lead to a change in food prices and affect the consumer surplus. However, local consumers may be affected, in particular if the markets are relatively isolated or if the production of specific local varieties is affected. If pollination services decline at a higher scale, i.e. a loss of pollinators manifesting itself at the national or continental scale, there are less alternative sources of supply, and price effects become likely. Consequently, larger scale ecological impacts are increasingly likely to result in price effects, and are likely to affect consumers' surpluses (cf. Freeman 1993).

With regards to the producer surplus generated by pollination services, it is clear that local farmers will experience a cost when they (partly) lose pollination in their fields. These costs may relate to reduced production, the need to switch to alternative crops giving lower returns or requiring new investments, or, in extreme cases, carrying out pollination by hand (Eardley et al. 2006). In case other producers are able to supply the same crop, they may benefit from higher market prices due to increasing scarcity of the crop. Hence, their gain may partly compensate for the loss of producers elsewhere. This price impact has to be accounted for when the pollination service is affected at a higher, e.g. a national, scale.

\subsection{Valuation Approach for the Pollination Service}

In the case of ecosystem services traded in a market, supply and demand curves can be constructed on the basis of price data. For public goods or services and private goods not traded in the market, a range of alternative valuation approaches have been developed, including revealed and stated preference methods (see e.g. Pearce and Moran 1994; OECD 1995; Van Kooten and Bulte 2000). Some of these alternative approaches result in a theoretically correct assessment of producer and consumer surpluses (e.g. the travel cost method or production factor methods), whereas other valuation methods lead to approximations of the surplus generated (such as the averting behaviour method).

The value of crop pollination can not be seen separately from the agricultural production process. Agricultural production depends on a range of inputs including labour, capital, land, inputs (e.g. seeds, fertilisers) and, for some crops, pollination. Hence, pollination can be interpreted as one of the inputs into agricultural production. Therefore, the production function approach is the valuation method that is most applicable for this service (Freeman, 1993).

Note that a different valuation method has also been proposed for valuing the pollination service, i.e. the replacement cost method (e.g. Allsopp et al. 2008). This method relates the value of an ecosystem service to the costs of an alternative way of obtaining the same benefits (e.g. Pearce and Turner 1990). For instance, the value of pollination by wild bees can be analysed on the basis of the costs of bringing in managed bees, or the value of pollination as a whole can be valued on the basis of the costs of hand pollinating crops in the absence of insect pollinators (as described in Eardley et al. 2006). However, for this study, the object of the valuation is the pollination service as a whole, covering both wild and managed populations, and there are few cases in the world where hand pollination is actually conducted. Hence, the production factor method is used for this study to explore how the value of the pollination service depends on scale.

The production function approach consists of a two-step procedure. First, the physical effects of changes in ecosystem services supply on an economic activity are assessed. Second, these impacts are valued in terms of the corresponding change in the marketed output of the corresponding activity.

The method is applied to the pollination service below for an agricultural production process in which output $(y)$ depends on an ecosystem service such as pollination $(e)$ as well as other production factors such as land and capital investments. Output sells for a price $(p)$. The social welfare (production plus consumer surplus) generated by the production of $y$ is $\mathrm{W}(y)$. In a perfectly functioning economy, under the assumption that every farmer is a price-taker, the competitive equilibrium production $y^{*}$ is reached at the welfare optimum (Freeman 1993). Considering the first order conditions for the welfare function, the change in welfare for a marginal change in the supply of an ecosystem service q can be expressed as:

$$
\frac{\partial W}{\partial e}=p\left(y^{*}\right) \cdot \frac{\partial y}{\partial e}
$$

Note that $\delta y / \delta e$ is the increase in y that would occur holding all other inputs constant (Freeman 1993). In case of a non-marginal change in the supply of an ecosystem service $e$, integration of the social welfare function over $e$ is required. This requires analysis of the production and cost 
functions, as well as the equilibrium production $y^{*}$ over different levels of $e$. Hence, for non-marginal changes, analysing the value of the pollination service requires construction of the demand and supply curves.

Hence, the valuation method works out differently at the local versus the national scale. If the local value of a pollination service is examined, prices for factors and products are not affected by changes in the pollination service, in particular if the crop is produced for the national or global market. In this case, it can be assumed that a change in pollination has a marginal impact on social welfare $W$. Because there is no price effect, the consumer surplus can be assumed to be zero, and the change in generated economic value is the result of a change in the producer surplus only. For instance, following Equation (1), the value generated by the pollination service in a farm can be calculated with Equation (2).

$W=S \cdot \Delta q \cdot(p-c)$

with $W=$ Welfare implications $(€)$;

$S=$ area under production (ha);

$\Delta q=$ increase in productivity $(\mathrm{kg} / \mathrm{ha})$ as a consequence of pollination;

$p=$ farm-gate price of the crop $(€ / \mathrm{kg})$;

$c=$ variable costs related to crop harvest $(€ / \mathrm{kg})$.

This equation is, however, valid in the short term only. In the longer term, in case of a high drop in crop production $\Delta q$ following loss of the pollination service, the farmer may switch to alternative production methods in order to reduce fixed costs or to alternative crops. The second adaptation (growing different crops) may be constrained by the need for new investments (e.g. the farmer needs to acquire knowledge on how to grow the new crop, or to invest in new irrigation equipment, etc.). In addition, the producer surplus calculated through Equation 2 is, strictly speaking, only valid in case there are no substitute crops for the farmer. If there are substitute crops, the farmer may switch to a new cop if a decrease in the pollination service would reduce income to less than the income that could be achieved with the substitute crop.

At a higher institutional level, e.g. the national scale, the impact on the overall market supply can no longer be ignored, and changes in the consumer surplus need to be calculated. Hence, a demand curve needs to be constructed based on historical price data. The producer surplus also needs reconsideration. First of all, producers are faced with a loss of income earning opportunities, that may be partially be compensated by switching to substitute crops. Second, there may be price increases following a loss of pollination at the national scale, which may increase the revenues for producers that continue production of the crop in spite of a reduction in productivity due to a loss of pollination services. Depending on the price elasticity and the extent to which the pollination service is affected, changes in producer surplus may be positive or negative. In case a significant part of the crop is exported, separate demand curves have to be constructed for the exported versus the nationally consumed commodities, as foreign consumers can more easily switch to supply from other countries (Kevan and Phillips 2001).

\section{THE VALUE OF THE POLLINATION SERVICE AT DIFFERENT SCALES; A REVIEW}

\subsection{Pollination as an Ecosystem Service}

Pollination has been classified in MA (2003) as a supporting service, i.e. a service that contributes to human welfare by maintaining or enhancing other services. In the case of pollination, the service is required for the production of a wide range of agricultural crops as well as for maintaining the reproduction processes in natural ecosystems. However, the service can also be classified as a regulation service (De Groot et al. 2002; Hein et al. 2006). For example, if pollinators residing in an ecosystem pollinate fruit trees in a nearby orchard, valuation of the services provided by the ecosystem needs to include pollination of the nearby orchard. Whereas the fruit is the final product (e.g. Boyd and Banzhaf 2007), it is pollination rather than fruit that is the service provided by the ecosystem.

Wind-pollinated crops and tuber species represent the major source of energy in the human diet (FAO 2004), but insect-pollinated crops are critical for the supply of vegetable proteins (soybean, oil palm, rape seed, beans, peas), dietary fibres (vegetables), vitamin A and C (fruits and vegetables) and to provide for a balanced and varied diet. In addition, insect-pollinated crops are widely used for cattle feeding (e.g. alfalfa, soybean). For instance, in the US, over 100 crops are insect-pollinated, of which 50 by honeybees (O'Grady 1987), and $15-30 \%$ of the average American diet is comprised of insect-pollinated foods (McGregor 1976, O'Grady 1987, Free 1993).

Hence, insect pollination is essential for global agriculture and human food security (see also Table 1). Some fruits and vegetables require insect-mediated pollination for the production of the fruit or vegetable itself, such as almonds, apples, apricots, blueberries, cantaloupes, citrus, cucumbers, kiwi, peach, plum, squash, sunflower and watermelon. For other fruits or vegetables, insect pollination is not a strict requirement for fruit bearing, but it substantially increases yields (e.g. tomatoes, coffee) (e.g. Klein et al. 2007). In addition, a large number of fruits and vegetables requires insect pollinators for seed production (Kremen et al. 2001). Sustaining global agriculture depends on pollination by managed bee populations, as well as on wild insects including wild bee populations, as discussed below.

The main insect group involved in managed pollination are the bees, and in particular the honey bee (genus Apis). The European honey bee is, by far, the most widespread domesticated bee. Despite of the important production of honey worldwide (1 272000 tons, FAOSTAT 2002) the role of honey bees as a pollinator remains the most important economic contribution, outweighing the importance of all the other hive products together (Apiservices 2003). Honey bees can be easily kept, and are capable of pollinating a wide spectrum of plants. It has been estimated that, worldwide, close to 100 crops are pollinated by honey bees (Mc Gregor 1976). Other bees that are widely used for pollination in agriculture are bumblebees (Bombus spp.), leafcutter bees (Megachile spp., in particular M. rotundata) and mason bees (Osmia spp, in particular O. lignaria.). Bumble bees are used, for instance, for tomatoes, eggplants, peppers, melons, raspberries and blackberries (Smith-Heavenrich 1998). 
Table 1. List of Major Insect-Dependent Crops

\begin{tabular}{|c|c|c|c|}
\hline Crop & Latin Name & Main Pollinator & Insect Dependency \\
\hline Apple & $\begin{array}{l}\text { Malus } \\
\text { domestica }\end{array}$ & $\begin{array}{c}\text { European honeybee (Apis mellifera), Asiatic honeybee (Apis cerana), Digger bees (Andrena } \\
\text { spp), Bumble bees (Bombus spp.), Mason bees (Osmia spp) }\end{array}$ & $80-100 \%$ \\
\hline Coconut & Cocos nucifera & European honeybee (Apis mellifera), Asiatic honeybee (Apis cerana), Ants & $10-40 \%$ \\
\hline Coffee & Coffea Arabica & European honeybee (Apis mellifera), Asiatic honeybee (Apis cerana), & $20-40 \%$ \\
\hline Grape & Vitis vinifera & European honeybee (Apis mellifera), Asiatic honeybee (Apis cerana), & $0-10 \%$ \\
\hline Orange & Citrus spp. & $\begin{array}{c}\text { European honeybee (Apis mellifera), Asiatic honeybee (Apis cerana), Rock bee (Apis } \\
\text { dorsata), Golden wasp (Vespa magnifica), Oriental wasp (Vespa orientalis), Red pumpkin } \\
\text { beetle (Aulacophora foveicollis), } \\
\text { Housefly (Musca domestica) }\end{array}$ & $10-30 \%$ \\
\hline Mango & $\begin{array}{l}\text { Mangifera } \\
\text { indica }\end{array}$ & European honeybee (Apis mellifera), Asiatic honeybee (Apis cerana), & $80-100 \%$ \\
\hline Melon & Cucumis melo & $\begin{array}{c}\text { European honeybee (Apis mellifera), Asiatic honeybee (Apis cerana), Halictidae } \\
\text { lassioglossum }\end{array}$ & $80-100 \%$ \\
\hline $\begin{array}{l}\text { Cucumber and } \\
\text { gherkins }\end{array}$ & $\begin{array}{l}\text { Cucumis } \\
\text { sativus }\end{array}$ & $\begin{array}{l}\text { European honeybee (Apis mellifera), Asiatic honeybee (Apis cerana), Lady beetle } \\
\text { (Coccinella spp), Red pumpkin beetle (Aulacophora foveicollis). }\end{array}$ & $50-90 \%$ \\
\hline Oil palm fruit & $\begin{array}{l}\text { Elaeis } \\
\text { guineensis }\end{array}$ & Various & $0-10 \%$ \\
\hline $\begin{array}{l}\text { Onion }+ \text { shallots } \\
\text { (seed production) }\end{array}$ & Allium cepa & $\begin{array}{c}\text { European honeybee (Apis mellifera), Asiatic honeybee (Apis cerana), Syrphid fly (Milesia } \\
\text { semiluctifer), Halictid bees, Drone flies }\end{array}$ & $90-100 \%$ \\
\hline Peanuts & $\begin{array}{l}\text { Arachis } \\
\text { hypogea }\end{array}$ & European honeybee (Apis mellifera), Asiatic honeybee (Apis cerana) & $10 \%$ \\
\hline $\begin{array}{l}\text { Squash and } \\
\text { pumpkin }\end{array}$ & Cucurbita spp. & Squash bee (Peponapis pruinosa), Halictus tripartitus & $90-100 \%$ \\
\hline Soybean & $\begin{array}{l}\text { Glycine max, } \\
\text { G. soja }\end{array}$ & European honeybee (Apis mellifera), Asiatic honeybee (Apis cerana), & $10 \%-40 \%$ \\
\hline Seed cotton & Gossypium spp. & Various & $20-30 \%$ \\
\hline Sunflower & $\begin{array}{l}\text { Helianthus } \\
\text { annuus }\end{array}$ & $\begin{array}{c}\text { European honeybee (Apis mellifera), Asiatic honeybee (Apis cerana), Bumble bees } \\
\text { Long-horned bees }\end{array}$ & $50-100 \%$ \\
\hline Rapeseed & $\begin{array}{c}\text { Brassica napus } \\
\text { oleifera }\end{array}$ & $\begin{array}{c}\text { European honeybee (Apis mellifera), Asiatic honeybee (Apis cerana), Lady beetle } \\
\text { (Coccinella spp), Bumble bee (Bombus spp), Syrphid fly (Milesia semiluctifer), } \\
\text { Carpenter ant (Xylocopa spp) }\end{array}$ & $50-100 \%$ \\
\hline Tomato & $\begin{array}{l}\text { Lycopersicon } \\
\text { esculentum }\end{array}$ & $\begin{array}{l}\text { Halictid bees (Halictidae spp.) (field) } \\
\text { Bumble bees (Bombus spp.) (greenhouse \& field), Honey bees (Apis mellifera \& other spp) }\end{array}$ & $10-50 \%$ \\
\hline Water melon & $\begin{array}{l}\text { Citrullus } \\
\text { lanatus }\end{array}$ & $\begin{array}{c}\text { Yellow face bumble bee (Bombus vosnesenskii), California bumble bee (Bombus } \\
\text { californicus), Squash bee (Peponapis pruinosa), Sweat bees (Halictus spp.), Long-horned } \\
\text { bees (Melissodes spp.) }\end{array}$ & $70-100 \%$ \\
\hline
\end{tabular}

Sources: Gordon and Davis, 2003; Roubik, 2002; Freitas, 2005; Klein et al., 2007.

Bumble bees are also widely used for tomatoes in greenhouses, which honey bees can not effectively pollinate. In total, more than 300,000 colonies are reported to be in use in greenhouses in Europe and North America (Greer 1999). Leafcutter bees are used for specific crops such as legumes and, especially, alfalfa, in particular in the US (Batra 1994). The solitary mason bees are effective pollinators at low temperatures $\left(<12{ }^{\circ} \mathrm{C}\right)$ when honey bees are not yet active, and they are used for early-blooming fruits like apples and pears (Vicens and Bosch 2000).

In addition to pollination from managed bee populations, the importance of wild insect populations for pollination is becoming increasingly clear (e.g. Winfree et al. 2008; Hoehn et al. 2008). For example, Greenleaf and Kremen (2006) experimentally investigated tomato pollination by wild bees in North Californian. Although this crop is generally considered self-pollinating, they found that wild bees substantially increase the production of field-grown tomato in northern California.

\subsection{The Value of the Pollination Service at Different Scales}

Local

Most valuation studies of the pollination service have been conducted at the local level, mostly in OECD countries, and in particular in the US. For instance, Siebert (1980) examines the costs of a loss of pollination related to pesticide 
use for Californian almond growers, and Olmstead and Wooten (1987) report on the value of alfalfa pollination by leafcutter bees in several US states. More recently, Kremen et al. (2002) provide a detailed assessment of the impact of bee pollination on watermelon yields in a county in California. In developing countries, less information is available. The one crop for which pollination has, however, been studied in detail is coffee (Ricketts 2004). Coffee is the worlds' highest value agricultural crop, and it has recently become clear that pollination contributes significantly to coffee yields (e.g. Roubik 2002; Klein et al. 2003). Most studies have focused on the local value of coffee pollination. For instance, Ricketts et al. (2004) studied the local value of coffee pollination in a Costa Rican coffee plantation. He found that enhanced pollination of coffee plants near forest edges led to a $20.8 \%$ higher yield in comparison with coffee plants in the centre of the fields. The forest patches provide a habitat to non-native honey bees as well as 10 native species of stingless bees, that all pollinate coffee. Considering the differences in coffee yields, coffee prices, and the variable prices of coffee production, they found that the annual surplus generated by the remaining forest patches on the plantation was US\$ 62,000 , representing $7 \%$ of the annual income of the plantation (Ricketts et al. 2004).

All local studies used the simple approach described in Equation 2 to calculate the local producer surplus. In the case of crops grown in OECD countries (where farmers normally produce for the national or international markets), the assumption of these studies that there is no consumer surplus is justified. However, the same approach can not be used, for instance, to assess the local value of pollination for food production in isolated markets in developing countries, when farmers mainly produce for local or autoconsumption. Note also that most local studies do not provide sufficient guidance for the management of the pollination service. For instance, it can not be derived from this experiment how much forest patches need to be preserved in order to maintain the pollination service in a coffee plantation; either more (if not all coffee fields are sufficiently pollinated) or less (if populations could do with smaller habitats) forest patches could be optimal for the farmer. An exception is the study of Olschewski et al. (2006), who study the marginal value of the pollination service in forest patches near coffee fields in Indonesia and Ecuador. They found the marginal value of forest patches to depend on the amount of forest converted, and noticed that pollination service alone does not provide economic justification for forest conservation in the two studied areas.

\section{National}

There are several studies that analyze the value of pollination services at the national scale, in particular for the US, several European countries, Australia and New Zealand (see Table 2). For these countries, there is relatively much information on the impact of pollination on crop productivity per crop (the first step of the production factor method). Comparing different studies, there appears to be some remaining uncertainty in the impact of pollination on crop production, depending on the crop and the crop variety (e.g. McGregor 1976; Free 1993; Buchmann and Nabhan 1996; Morse and Calderone 2000; Klein et al. 2007), see also Table 1. However, this uncertainty is low compared to the remaining uncertainty in the translation of the ecological impact into an economic value. There is relatively little experience with analyzing the economic value of pollination, in particular at higher scales. Very few studies have attempted to measure consumer and producer surpluses generated by the pollination service, as discussed below.

Southwick and Southwick (1992) consider the consumers' and producers' surpluses related to the pollination service with respect to crop pollination in the USA. They assume that profits of the producers, in the long-run, are eliminated by the entry of new farmers, and that the producers' surplus related to pollination is zero. This however, is a debatable assumption as it assumes a zero resource rent for agricultural producers, which will only be the case in case of unlimited availability of new agricultural land. Consequently, Southwick and Southwick (1992) assumed that all the benefits of pollination accrue to consumers, principally because pollination reduces the prices of agricultural products. Based on some 20 years of price and consumption data, Southwick and Southwick estimate the demand curve for 50 different crops. On the basis of these assumptions, the total value of honey bee pollination for US agriculture is calculated to be US\$ 6.0 billion.

Gordon and Davis (2003) examined the value of honey bee pollination in relation to 35 crops grown in Australian agriculture. Gordon and Davis (2003) estimated both the consumers' surplus and the producers' surplus related to honey bee pollination. For the demand curve, the study accounts for the effect that Australian consumers can replace Australian products by imported ones, if the Australian products become too expensive following the loss of the pollination service. Both the elasticity of the domestic demand and the elasticity of the export demand are calculated. The latter is around 10 times the domestic demand elasticity as, on the international market, Australian products can in many cases relatively easily be replaced by products from other countries. The producers' surplus is calculated for three assumptions regarding the loss of income that farmer will incur before they switch to another crop following a decline in the pollination service. Calculations are carried out for switching at a $0 \%, 30 \%$ and $100 \%$ loss. If farmers, following a loss of the pollination service, immediately switch to a new crop that does not depend on pollination (the $0 \%$ assumption), the producers' surplus is zero (equivalent to Southwick and Southwick 1992). Additional calculations are made for a $30 \%$ and $100 \%$ acceptance of income loss before farmers switch to new crops - which corresponds to a situation in which farmers have few alternative crops to grow. Gordon and Davis (2003) calculate the consumers' surplus of the service in Australia to be AU $\$ 839$ million, and the producers' surplus respectively 0 (producers immediately switch to other crops), AU\$ 452 million (producers switch to other crops at 30\% income loss), or AU\$ 887 million (producers switch to other crops at $100 \%$ income loss).

Many other studies provide estimates of the national values of the pollination service based on (the theoretically incorrect) multiplication of crop increases with prices (e.g. Borneck and Bricout 1984; Levin 1984; Winston and Scott 1984; Carreck and Williams 1998; Borneck and Merle 1989; Morse and Calderone 2000). These various studies estimate 
Table 2. Comparison of the Value Estimates of the Reviewed Case Studies

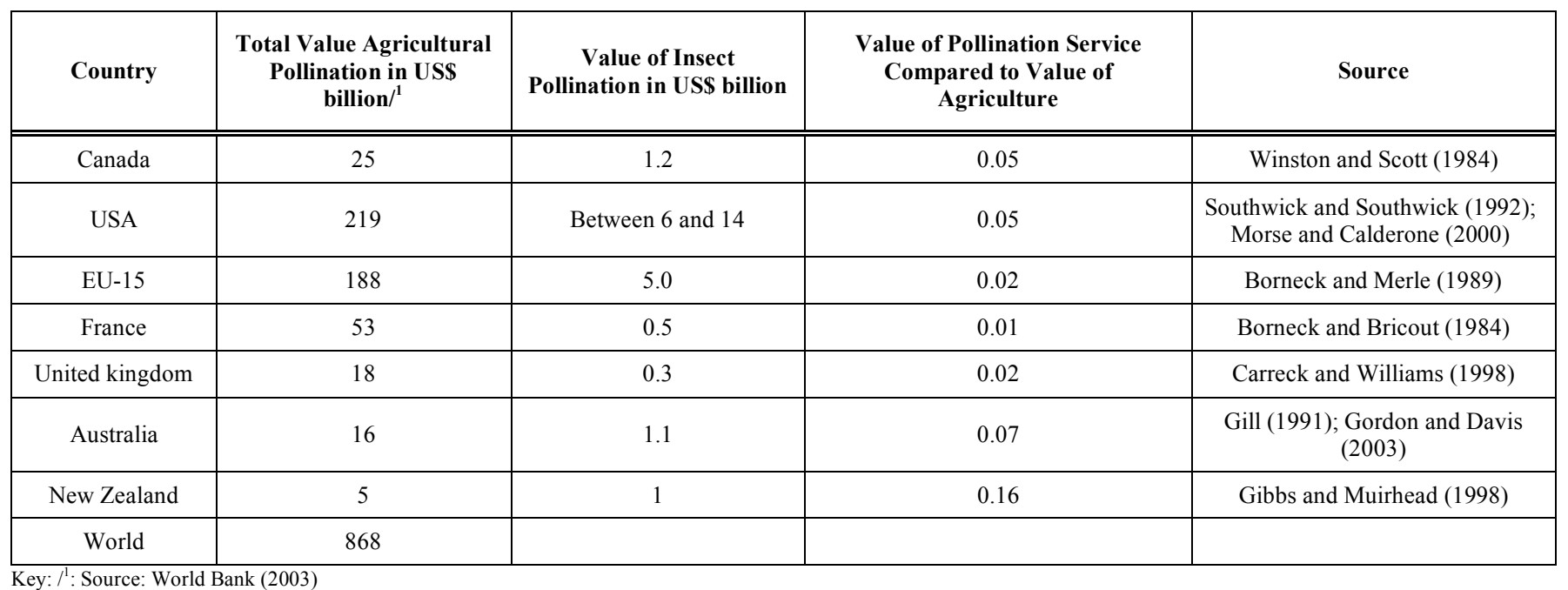

the value of the pollination service to contribute between several up to $16 \%$ of the value of the total agricultural production of the countries analyzed (see Table 2). The highest value is found for New Zealand, which may be related to the dependence of kiwifruit $(>90 \%)$ on pollination (Klein et al. 2007). However, this approach may over or underestimate the surpluses generated by pollination, depending on the price elasticity for the crops involved, and these studies do therefore not present accurate assessments of the economic value of the service. Overall, there is much less information on the value of pollination services at the national level compared to the local level.

\section{Global}

There have been several attempts to analyze the value of the pollination service at the global scale. Costanza et al. (1997) provide a value estimate of $\$ 117$ billion per year for all pollination ecosystem services, whereas Richards (1993) finds that the value of pollination in global agriculture alone amounts to $\$ 200$ billion per year. Gallai et al. (2009) estimate the economic value of the pollination services worldwide to be 153 billion euro (considering impacts on agriculture only). However, these value estimates focus on establishing the relation between pollination and crop production, and have assumed constant prices for crops. This is not a realistic approach in case a global decline in the pollination service is assessed, as such a decline would lead to major price increase of insect-pollinated crops (see sections above). Note that this is recognised in Gallai et al. (2009), who discuss the importance of price elasticity and show an approach for calculating global consumers (but not producers) surpluses related to crop pollination - however without applying this approach to determine a more reliable estimate of the global value of the pollination service.

Care also needs to be taken in case the economic impact of a loss of pollination services on a range of crops is analysed. Price elasticity is normally measured for one or a basket of specific products, e.g. an orange, assuming that the availability and price of substitute good does not change (Varian 1993). It is very difficult to predict the elasticity that would apply in the case the supply of a whole group of products (i.e. all insect-pollinated fruits) would be impaired at the global scale. This may lead to a strong increase in food prices and reduced food security. Hence, there is currently no reliable information on the global value of the pollination service.

\section{DISCUSSION AND CONCLUSIONS}

Currently, the most comprehensive assessments for the value of the pollination service are available for Australia, the USA and the UK (see Table 2). However, at the national level, there are few studies that use a correct approach of estimating consumers' and producers' surpluses (e.g. Southwick and Southwick 1992). Many studies base their estimate of the economic value of pollination on a mere multiplication of impacts on production with current farmgate prices (e.g. Levin 1984; Morse and Calderone 2000). Gordon and Davids (2003) show that the sum of the consumers' and producers' surplus can be both lower or higher than the multiplication of potential production losses with farm-gate prices, depending on the price elasticity of the crop involved. Caution needs to be taken in the interpretation of valuation studies that follow strongly simplified methodologies.

There are currently no reliable indications of the value of the pollination service at the global scale. Global impacts may lead to major changes in food supply and food security. Whereas the main staple crops are wind-pollinated, (partly) insect-pollinated crops, or crops that require pollination for seed production, such as beans, onions, cucumbers, water melons, sweet potatoes, carrots and cabbages are essential elements of the human diet in a large number of countries. In case a multitude of crops is affected simultaneously by a reduction in pollination, strong price effects may occur and these price effects can not be extrapolated from currently established supply and demand curves for single crops in specific countries.

There is a need for studies that conduct a valuation of the pollination service to transparently define the assumptions 
underlying the valuation method. A key element in this process is defining the scale of the analysis: can price impacts and, consequently, a change in the consumers' surplus be expected. If so, then demand curves need to be established to analyse the economic value of the service. Only in case local production does not have an impact on market prices in local or national markets, the consumers' surplus of pollination can be assumed to be zero (as in Ricketts et al. 2004).

A second element is the need to identify if a loss of pollination will affect only one crop, or if a multitude of crops will be impacted. If crops that could substitute for each other both experience a reduction in market supply, demand curves that are established under the assumption that alternative crops are available may not be valid. For instance, European consumers may chose to eat oranges in a year with low apple harvests and high apple prices (e.g. because of late frost). If a demand curve is based on these market data, there is the implicit assumption of the availability of a substitute crop. However, in case of a global loss of pollinators, e.g. because of a new disease affecting honey bees globally, both apple and orange production would be affected and this demand curve would no longer be valid.

With regards to the producers' surplus, a critical element in the calculation is the assumed availability of alternative pollinators and alternative crops to farmers. If commercial pollinators can be brought in, the costs of doing so represent the maximum benefits that a farmer obtains from natural pollination. However, clearly, if commercially available pollinators are also affected, for instance due to a loss of beehives because of diseases, crop production and farmers' surpluses will be strongly affected when natural pollinators decline. In case farmers need to switch to new crops, it needs to be analysed if these crops generate lower net revenues for the farmer, or if there are costs related to switching to alternative crops (e.g. new farm equipment or new processing or storage facilities).

In conclusion, it is the transparency of the underlying assumptions, and the ecological and agronomical detail driving the economic valuation approach, that determine the value of the pollination study. In analysing the value of the pollination service at the national or global scale, price changes as a consequence of reduced supply of agricultural commodities must be taken into account. More research is needed in order to obtain a comprehensive and complete picture of the value of pollination services, in particular at the national and global scales.

\section{REFERENCES}

Allen-Wardell, G, Bernhardt, P \& Bitner, R (1998) The potential consequences of pollinator declines on the conservation of biodiversity and stability of food crop yields. Conservation Biology, 12, 8-17.

Allsopp MH, de Lange WJ \& R Veldtman (2008) Valuing insect pollination services with cost of replacement. PLoS ONE 3 (9) (September 2008) http://www.plosone.org e3128.

Balmford, A, Bruner, A, Cooper, P, Costanza, R, Farber, S, Green, R, Jenkins, M, Jefferiss, PV, Jessamay, J, Madden, K, Munro, N, Myers, S, Naeem, S, Paavola, J, Rayment, S, Rosendo, J, Roughgarden, K, Trumper, K \& Turner, RK (2002) Economic reasons for conserving wild nature. Science, 297, 950-53.
Batra, S (1994) Diversify With Pollen Bees. American Bee Journal, 9, 1217.

Berkes, F \& Folke, C (1998) Linking Social and Ecological Systems. Management practices and social mechanisms for building resilience. Cambridge University Press: Cambridge, UK, 459.

Biesmeijer, JC, Roberts, SPM, Reemer, M, Ohlemüller, R, Edwards, M, Peeters, T, Schaffers, AP, Potts, SG, Kleukers, R, Thomas, CD, Settele, J \& Kunin, WE (2006) Parallel declines in pollinators and insect-pollinated plants in Britain and the Netherlands. Science, $313,351-54$

Borneck, R \& Bricout, JP (1984) Evaluation de l'incidence économique de l'entomofaune pollinisatrice en agriculture. Bulletin Technique Apicole 11, 117-24.

Borneck, R \& Merle, B (1989) Essai d'une evaluation de l'incidence economique de l'abeille pollinisatrice dans l'agriculture européenne. Apiacta 24, 33-38.

Boyd, J \& Banzhaf, S (2007) What are ecosystem services? The need for standardized environmental accounting units. Ecological Economics, 63, 616-26.

Buchmann, SL \& Nabhan, GP (1996) The Forgotten Pollinators, Island Press: Washington, D.C., 126.

Carreck, NL \& Williams, IH (1998) The economic value of bees in the UK. Bee World, 79, 115-23.

Cash, DW \& Moser, SC (1998) Cross-scale interactions in assessments, information systems, and decision-making. Critical Evaluation of Global Environmental Assessments, Global Environmental Assessment Project, Harvard University, Cambridge, MA, 345-72.

Costanza, R, d'Arge, R, de Groot, RS, Farber, S, Grasso, M, Hannon, B, Limburg, K, Naeem, RV, O'Neill, J, Paruelo, RG, Raskin, P, Sutton, P \& van den Belt, M (1997) The value of the world's ecosystem services and natural capital. Nature, 387, 253-60.

Daily, GC, Ed. (1997) Nature's services. Societal dependence on natural ecosystems. Island Press: Washington, DC.

Diaz, S, Lavorel, S, de Bello, F, Quetier, K, Grigulis, F \& Robson, TM (2007) Incorporating plant functional diversity effects in ecosystem service assessments. Proceedings of the National Academy of Sciences, 104, 20684-89.

De Groot, RS, Wilson, MA \& Bouman, R (2002) A typology for the classification, description and valuation of ecosystem services, goods and services. Ecological Economics, 41, 393-408.

Eardley, C, Roth, D, Clarke, J, Buchmann, S \& Gemmill, B (2006) Pollinators and pollination: A resource book for policy and practice. African Pollinator Initiative (API), Pretoria: South Africa.

Free, JB (1993) Insect pollination of crops. $2^{\text {nd }}$ ed. Academic Press: London, UK.

Freeman, AM III (1993) The Measurement of Environmental and Resource Values: Theory and Methods. Resources for the Future, Washington, D.C. 341

Freitas, BM (2005) Pollination in Brazil, a stock-taking. FAO Consultancy Report, FAO, Rome. 57.

Gallai, N, Salles, J, Settele, J \& Vaissière, BE (2009) Economic valuation of the vulnerability of world agriculture confronted with pollinator decline. Ecological Economics, 68, 810-21.

Gibbs, D \& Muirhead, I (1998) The economic value and environmental impact of the Australian beekeeping industry. A report prepared for the Australian Beekeeping Industry, 30.

Gill, RA (1991) The value of honeybee pollination to society. Acta Horticulturac, 288, 62-68.

Gordon, J \& Davis, L (2003) Valuing honeybee pollination. Rural Industries Research and Development Corporation Paper 03/077, Canberra, ACT, Australia.

Greenleaf, SS \& Kremen, C (2006) Wild bees enhance honey bees' pollination of hybrid sunflower. Proceedings of the National Academy of Sciences, 103, 13890-95.

Greer, L (1999) Alternative Pollinators: Native Bees, ATTRA - National Sustainable Agriculture Information Service, Horticulture Technical Note, 73.

Hanley, N \& Spash, CL (1993) Cost-Benefit Analysis and the Environment. Edward Elgar: Vermont, 278.

Hein, L, van Koppen, K, de Groot, RS \& van Ierland, EC (2006) Spatial scales, stakeholders and the valuation of ecosystem services. Ecological Economics, 57, 209-28.

Holling, CS (1992) Cross-scale morphology, geometry and dynamics of ecosystems. Ecological Monographs, 62, 447-502.

Hueting, R (1980) New scarcity and economic growth. Agon-Elsevier: Amsterdam/New York, 305. 
Hueting, R, Reijnders, B, de Boer, J, Lambooy, J \& Jansen, H (1998) The concept of environmental function and its valuation. Ecological Economics, 25, 31-35.

Kevan, PG \& Phillips, TP (2001) The economic impacts of pollinator declines: an approach to assessing the consequences. Conservation Ecology, 5, 8-15.

Klein, AM, Steffan-Dewenter, I \& Tscharntke, T (2003) Bee pollination and fruit set of C. arabica and C. canephora. American Journal of Botany, 90, 153-57.

Klein, AM, Vaissière, B, Cane, JH, Steffan-Dewenter, I, Cunningham, SA \& Kremen, C (2007) Importance of crop pollinators in changing landscapes for world crops. Proceedings of the Royal Society of Biological Sciences, 274, 303-13.

Kremen, C, Adelman SW, Bugg, B \& Thorp, R (2001) Conserving and restoring pollination services in organic farms of Yolo and Solano Counties, Northern California, Wildlife Conservation Society, Dept. of Biological Sciences, Stanford University.

Levin, MD (1984) Value of bee pollination to United States agriculture. American Bee Journal, 124, 184-86.

Levin, SA (1992) The problem of pattern and scale in ecology. Ecology, 73, 1943-67.

Limburg, K, O’Neill, R, Costanza, R \& Farber, S (2002) Complex systems and valuation. Ecological Economics, 41, 409-20.

Marshall, G (1920) Principles of Economics, $8^{\text {th }}$ ed, Mac Millan; London.

McGregor, SE (1976) Insect Pollination of Cultivated Crops. USDA Agriculture Handbook No. 496, US Government Printing Office: Washington, D.C.

Millennium Ecosystem Assessment (2003) Ecosystems and Human Wellbeing: A Framework for Assessment. Island Press: Washington D.C.

Mitsch, WN \& Gosselink, JG (2000) The value of wetlands: importance of scale and landscape. Ecological Economics, 35, 25-33.

Morse, RA \& Calderone, NW (2000) The value of honey bees as pollinators of US crops in 2000. Report Cornell University: Ithaca, New York.

Needham, GM \& Bowman, CE (Eds.) Africanised honey bees and bee mites. Wiley, New York.

OECD (1995) The economic appraisal of environmental projects and policies, a practical guide. OECD, Paris.

Olschewski, R, Tscharntke, T, Benítez, PC, Schwarze, S \& Klein, A (2006) Economic valuation of pollination services comparing coffee landscapes in Ecuador and Indonesia. Ecology and Society, 11, 712.

Olmstead, A \& Woolen, DB (1987) Bee pollination and productivity growth: the case of alfalfa. American Journal of Agricultural Economics, 69, 56-63.

O'Riordan, T, Cooper, C, Jordan, A, Rayner, S, Richards, K, Runci, P \& Yoffe, S (1998) Institutional frameworks for political action. In Human choice and climate change, v.1: The societal framework. Battelle Press: Columbus, OH, 345-439.
Pearce, DW \& Moran, D (1994) The Economic Value of Biodiversity, Earthscan, London, in association with the IUCN.

Peterson, G (2000) Political ecology and ecological resilience: An integration of human and ecological dynamics. Ecological Economics, 35, 323-36.

Richards, KW (1993) Non-Apis bees as crop pollinators. Revue Suisse de Zoologie 100, 807-822.

Ricketts, TH, Daily, GC, Ehrlich, PR \& Michener, CD (2004) Economic value of tropical forest to coffee production. Proceedings of the National Academy of Sciences of the United States of America, 101, 12579-82.

Ricketts, TH (2004) Tropical forest fragments enhance pollinator activity in nearby coffee crops. Conservation Biology, 18, 1262-71.

Roubik, DW (2002) The value of bees to the coffee harvest. Nature, 417, 708.

Sanchirico, JM \& Wilen, JE (2005) Optimal spatial management of renewable resources: matching policy scope to ecosystem scale. Journal of Environmental Economics and Management, 50, 23-46.

Siebert, JW (1980) Beekeeping, pollination and externalities in California agriculture. American Journal of Agricultural Economics, 62, 165171.

Southwick, EE \& Southwick L (1992) Estimating the economic value of honey bees (Hymenoptera: Apidae) as agricultural pollinators in the United States. Journal of Economic Entomology, 85, 621-33.

Tansley, AG (1935) The use and abuse of vegetational terms and concepts. Ecology, 16, 284-307.

Van Kooten, GC (1993) Land Resource Economics and Sustainable Development: economic policies and the common good. UBC Press: Vancouver, 450.

Van Kooten, GC \& Bulte, E (2000) The economics of nature; managing biological assets. Blackwell Publishers Inc.: Malden, USA.

Varian, HR (1993) Intermediate micro-economics. $3^{\text {rd }}$ ed. W.W. Norton \& Company: New York, 451.

Vicens N \& Bosch J (2000) Weather-dependent pollinator activity in an apple orchard, with special reference to Osmia cornuta and Apis mellifera (Hymenoptera: Megachilidae and Apidae), Environmental Entomology, 29, 413-20.

Winston, ML \& Scott, CD (1984) The value of bee pollination to Canadian apiculture. Canadian Beekeeping, 11, 134

Willig, R (1976) Consumer's surplus without apology. American Economic Review, 66, 589-97.

Winfree, R, Williams, NM, Gaines, H, Ascher, JS \& Kremen, C (2008) Wild bee pollinators provide the majority of crop visitation across land-use gradients in New Jersey and Pennsylvania, USA. Journal of Applied Ecology, 45, 793-802.

World Bank (2003) World Development Indicators. World Bank: Washington D.C.

Received: February 04, 2008

Revised: April 02, 2009

Accepted: May 07, 2009

(C) Lars Hein; Licensee Bentham Open.

This is an open access article licensed under the terms of the Creative Commons Attribution Non-Commercial License (http://creativecommons.org/licenses/by$\mathrm{nc} / 3.0 /)$, which permits unrestricted, non-commercial use, distribution \& reproduction in any medium, provided the work is properly cited. 